\title{
Development Possibilities of the Green Economy in Latvia (Example of Rezekne Municipality)
}

\author{
Sintija Batare \\ Faculty of Economics and Management \\ Rezekne Academy of Technologies \\ Rezekne, Latvia \\ sintija.batare@inbox.lv
}

\author{
Daina Znotina \\ Business and Social Processes Research \\ Institute \\ Rezekne Academy of Technologies \\ Rezekne, Latvia \\ Daina.Znotina@rta.lv
}

\begin{abstract}
Preserving natural capital is important topic in $21^{\text {st }}$ century in order to ensure prosperity by sustaining qualitative ecosystem services that are both - non-material and material benefits provided by nature. As research outlines, green economy is based on three pillars of sustainable development - social, economic and environmental. It was concluded, that the main principles of the green economy are sustainable development, which stimulates economic growth, reduces poverty, while placing natural capital as a major asset; development adapted to the interests and opportunities of each country, regions and local areas ensuring participation of the population, social inclusion; promotion of green industries (renewable energy, waste management, sustainable agriculture); efficient use of natural resources.
\end{abstract}

Research paper analyses the current situation and future potential of Latvia in the implementation of the green economy, taking as the example evaluation of the situation in the Rezekne Municipality. Research methods such as logical constructive method, document analysis, and interviews were used to gather, analyse and reflect information which was then used to create evaluation model that was used in the focus group to assess weaknesses and potential of Rezekne Municipality, for example, potential in the production of gas from waste. Also important is education of society and their involvement in non-governmental organizations, and the development of the greener way of thinking, where there are noticeable weaknesses. It is possible to take direct examples from other countries (case studies from Finland, France, Lithuania, and Great Britain) that already have experience and real results.

Keywords - green economy, municipality, sustainable development.

\section{INTRODUCTION}

Over the last 100 years, mankind has changed world's ecosystems to such an extent that it has never been in its history. Consumption and production have caused various and rather severe environmental problems such as water scarcity, soil erosion, loss of ecosystems and biodiversity, natural cataclysms, climate change, etc. in many parts of the world. Some of these negative changes are irreversible. These changes are happening

due to the rapidly growing consumption of food, water, wood, fuel, minerals and other materials. This is the part of the traditional linear economic model: resourcesproducts-waste. Today that kind of thinking is considered unsustainable by policy makers and consumers alike.

Millennium Ecosystem Assessment (2013) revealed alarming statistics that $60 \%$ of the ecosystems are experiencing a global decline, so environmental renewal is recognized as crucial action [1]. Hence, sustainable development has become a necessity, otherwise humanity will not be able to fully exist. Successful investments in clean energy, energy efficiency, environmentally friendly construction, organic farming, waste recycling and waste generation can create an inevitable compromise between environmental protection and economic progress. It is recognized that the green economy can improve employment and reduce poverty while protecting and preserving natural capital [2]. It should also be emphasized that it is not just about investing in green sectors as positive results will only be visible after implementing a common strategic shift from a traditional economic model to a green economy that also includes a change in consumer lifestyle and consumption [3]. Regional and local level authorities and organisations play a key role in the green economy as they develop and shape economic, political and social policies at local, regional and national levels, impacting non-governmental organizations, businesses and citizens [4].

The aim of the research is to study the concept of green economy and its development opportunities in Latvia taking into account the example of Rezekne municipality and experience of other countries.

Methodology of the research: document analysis, interviews (example of France, Finland), focus group interview in Rezekne municipality. Employees of Rezekne Municipality Development Planning Department were selected as focus group participants, since it is this department that is responsible for the municipalities' development program, attraction of investments, public relations, establishment and planning of the territory, implementation of projects and other activities related to development. It is therefore necessary to assess whether 
activities of Development planning department are in accordance with the nature and principles of the green economy.

\section{THE CONCEPT OF GREEN ECONOMY}

The green economy as a concept is increasingly used worldwide highlighting the growing need to focus on a form of development that provides sustainability. The 2008 crisis gave a significant impetus to the concept of a green economy because the crisis focused not only on financial losses but also on the labour market and the housing market, which reflected the imbalance of the existing economic model [5]. United Nations Environment Programme included green economy as one of its crucial topics and defined it as an economic model that improves people's well-being and creates social justice while reducing environmental risks [6]. This definition is also directly based on the internationally recognized 3 pillars of sustainable development (Figure 1).

Sustainable development is based on the need to optimise and find the balance between economic development, social systems and environmental preservation. Without these 3 pillars, humanity will not be able to provide functioning economy, a harmonious society and a healthy environment.

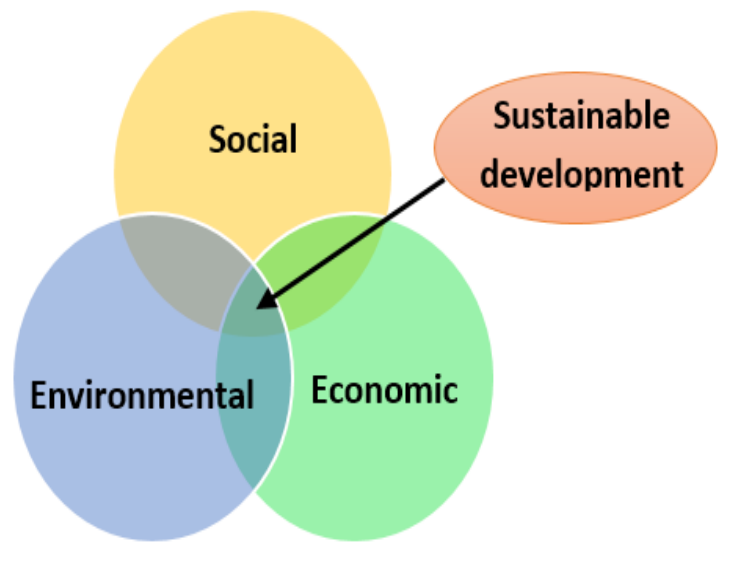

Figure 1. The three pillars of sustainable development [7].

Figure 1 reflects the need for united action in all 3 areas to achieve sustainable development at the crossroads of all three pillars. The environmental pillar includes solutions to the challenges in energy, biodiversity, natural resources and pollution. The objective of the economic pillar is to ensure development, efficiency and stability, while the social pillar covers social inclusion, empowerment and institutional and administrative cooperation with citizens and in the interests of the citizens. Some sources also mention the fourth pillar, which includes 'culture', thus emphasizing the promotion of cultural diversity and the protection of human rights [8], but according to the authors of the research, this can also be attributed to the social pillar.

As highlighted in the European Environment Agency report [9], the concept of a green economy is not yet clearly defined, although it was first mentioned already in 1989 in a study by leading environmental economists working for the British government [10]. Most commonly used definition is the previously mentioned United Nations Environment programmes version that "a green economy is one that results in improved wellbeing and social equity, while significantly reducing environmental risks and ecological scarcities (2011). European Environment Agency defines green economy as the "one that generates increasing prosperity while maintaining the natural systems that sustain us" (2014). Authors of the research noted that although the EU institutions (including the European Commission) are actively involved in the implementation of sustainability and green economy activities, no formal definition of the green economy has been proposed.

After the research authors can define green growth as a social and political movement of interaction and development of social, economic and environmental capital, which has led to a new concept of economic development - a green economy that emphasizes the need for increased attention to environmental aspects to provide also economic benefits and prosperity.

After analysing information from various sources, the authors of the paper came to the conclusion that the principles of the green economy are:

- Sustainable development, which stimulates economic growth and therefore reduces poverty, while putting natural capital at the forefront;

- Development tailored to the interests and opportunities of each country and its regions and local areas;

- Defining and coordinating concrete and clear policies at all levels of government with specific objectives and deadlines;

- Ensuring citizens' participation, social inclusion, stability;

- Involvement and cooperation of all stakeholders;

- Growth are measured by different indicators without focusing so much on GDP growth;

- Promotion of green industries (renewable energy, waste management, sustainable agriculture, etc.);

- Efficient use of natural resources and GHG reduction to mitigate climate change.

\section{EXPERIENCE OF IMPLEMENTING GREEN ECONOMIC ASPECTS IN OTHER COUNTRIES AND REGIONS}

\section{Finland}

The municipality of Turku is the oldest and one of the largest cities in Finland. The population in this municipality reaches almost 200 thousand, of which 40 thousand people are students. Within the framework of the study, the author contacted Alina Heywood, one of the members of the Green Party of the Turku Municipal Council. Her party is working in the direction of the green economy, and she shared her experience of working in the municipality in an interview. Alina admits that she has been interested in ways to help people and nature since childhood, without threatening nature and without affecting the climate. It was one of the reasons why she was already involved in party activities at the age of 16 , which, in the authors' opinion, also partly shows the 
importance of environmental education from an early age and the public's initiative and ability to engage in activities.

The Green Party was founded in 1987, the founders of this party were the activists of the Koijärvi-movement (Koijarvi Movement), which united to save Lake Koijarvi from drying out as an important bird nesting site. The main values of the party are responsibility, freedom and care for nature. Currently, the party is also working to achieve a fair employment system and to reduce unemployment, as well as to reduce poverty and improve the education system.

All decisions in the Turku municipality are taken by the municipal administration, the council and committees that focus on specific areas. The city council is elected every four years in municipal elections and thus takes all final decisions. The Green Party has become the second largest party in the Turku municipality, so it has been more likely to influence decisions in recent years. The Green Party has implemented a number of successful projects in the city, such as the creation of a new development strategy to turn Turku into a modern city that attracts more young people and, by 2029 , to become a city that is free of carbon emissions. There was also recently launched a city bicycle sharing system to create a cycling friendly environment. In the future, the Green Party plans to renew the tram movement in the city of Turku, which would promote the use of public transport. The Green Party fellow believes that the key preconditions for sustainable social and municipal development are the awareness of the past and current problems and planning of the future, as well as critical thinking. A.Hieywood believes that sustainable decisions are made when the municipality is aware of the real situation and decisionmaking takes place in a transparent and open way, rather than hiding the process from the public.

\section{Lithuania}

An important aspect of sustainable development, which is currently being implemented in Lithuania, is the introduction of a waste recycling system. On February 12, 2018, the media reported the construction of a "revolutionary" waste and biomass cogeneration unit in Vilnius district. The total cost of the project is EUR 350 million provided by a loan from the European Investment Bank (190 million) and EU support. The construction of a cogeneration plant is the largest energy project in Lithuania and aims to reduce the amount of disposed household waste, reduce energy prices, reduce emissions and improve security of energy supply [11]. The work is scheduled to start at the end of 2019, and it will be one of the most modern of its kind in Europe. The construction process will provide 750 jobs, while the station itself will have 100 jobs and will be able to supply half of the customers using heating and electricity system of the Vilnius district. It should reduce the costs of fuel by 13 million euros and save 10 million euros on waste management. After survey of population, $72 \%$ of the residents supported the construction of the station [12]. This project was based on the fact that a waste sorting plant was opened a few years ago, which collects waste from the entire Vilnius district. In total, there are 11 waste sorting plants in Lithuania - two waste sorting plants in Kaunas and one for each of Vilnius, Klaipeda, Šiauliai, Panevėžys, Alita, Marijampolè, Utena, Telšiai and Taurage [13]. Thus, it can be concluded that Lithuania has made significant investments in waste management, which Latvia could take as an example, only in this case large investments are needed. Without the support and strategic approach of the European Union it is impossible to implement these changes at national and regional level.

\section{France}

Roubaix, the municipality in northern France is a great example of how the municipality itself can shape its active policy towards sustainability to a large extent, regardless of the shortcomings of national legislation. The former employee of the municipality of Roubaix and now the zero-waste activist Lucie Dupont informed the author of the interview that the northern region, and especially the municipality of Roubaix, was long regarded as the most underdeveloped and "poorest" since the region was formerly industrial based, but over time many of the factories have closed. Since waste policy is set at national level and organized by associations and regions, local government was not able to influence it, so it was decided to carry out activities within the municipality itself. In the local elections in 2014, a party that was different from the traditional won because their strategic goal was implementing a waste-free direction in the municipality.

In order to attract residents to start a waste-free lifestyle, in 2015, the municipality of Roubaix launched a 1-year voluntary challenge for families and 100 households applied for the first challenge. According to L.Duponte, the expenditures of the municipality itself were not big - small scales for waste weighting for each family and the salary for one additional municipal employee (parttime) had to be provided. Employee informed, helped and evaluated the results of the families involved in the challenge a few days a week. The results were significant among these families - $25 \%$ of households reduced their waste by $80 \%$ and $70 \%$ of households reduced their waste by $50 \%$ [14]. Involving families in such an activity was a key driver of the strategy.

The waste-free strategy also included activities in schools that focused on reducing lunch surpluses, implementing composting and using non-disposable tableware. As a result, management wants to introduce specific guidelines for schools that can be promoted outside of the municipality of Roubaix. Businesses and shops were motivated to incorporate a waste-free strategy into their business models, saving resources and finances, for example, by offering their product without unnecessary packaging, selling in bulk, etc. As this type of lifestyle develops among the public, there is a growing demand for the "right kind" of services that businesses and shops can offer. These municipal methods for promoting sustainability and changing consumption habits and behaviour of consumers are an inspiring example of how positive results can be achieved without investing large amounts of money but properly motivating and inspiring.

\section{Great Britain}

Green economy initiatives have not always been successful. One of the most unsuccessful initiatives has 
been the Green Deal policy of the British government, launched in 2013, when citizens were offered to introduce energy-saving technologies into their homes by including them in an energy bill, the so-called "payas-you-save" model [15]. Citizens were able to take energy-saving measures in their homes, such as installing housing insulation, improving the heating system, testing the design of the house, installing double glazing of windows, and installing appliances that produce energy from renewable energy sources (solar cells / panels, heat pumps) [16].Unfortunately, the initiative only lasted for 2.5 years and only ended because it did not produce the desired result. The initiative was participated by only 6,000 dwellings per year and a total of 14,000 dwellings, although it was planned that 14 million households would be involved in the program by 2020 , i.e. 2 million a year [17]. Overall, it was concluded that there are 3 main reasons for failing (1) ineffectual regulation of the initiative; (2) limited financial gain; (3) wrong approach to consumer preferences [18].

The unsuccessful regulation of the initiative manifested because, in order to make an attractive offer for citizens, no specific requirements were set for improvement, so the result was unclear, so more expensive measures like renovation were excluded. Financial benefits were hampered by the fact that the Green Deal rates were much higher than the market rates. In turn, the biggest drawback was the wrong approach to consumers. The green deal was only positioned as financial savings, but it is too narrow a direction, although the financial aspect is significant. Initiative marketing did not focus on people's needs such as the positive impact of the initiative on comfort, well-being and health [19], [20]. From the case of the UK, it can be concluded that national activities need to be planned with particular care, and a great deal of emphasis should be placed on the motivation of the people and their willingness to give them what they want, including the aspects of green technology, so that innovation becomes demanded among the population. Successful green initiative also requires successful marketing to achieve its positive impact.

As can be seen from the examples of European countries examined, green economy activities should be started by identifying their significance at the national level, incorporating its principles into the national level development planning documents, followed by the example of the regional and local government strategy. The British and Finnish municipalities shows examples where the first way of action to a green economy was the creation of an appropriate sustainable strategy. It is also important to identify the weaknesses in each area and administration that allow them to be corrected. Activities also need to be implemented in the regions in order to achieve steady development and offer equal opportunities to all citizens of the country. Public participation has played an important role in these examples, and the potential and image of green activities have been promoted by associations and movements. It should also be accepted that sometimes the implementation of the activities can immediately fail to deliver the expected results and even fail as in the case of the UK. Thus the approach to the consumers should change and also appropriate communication plan with the public for the green activities should develop.

\section{IMPLEMENTATION OF THE GREEN ECONOMY ASPECTS IN REZEKNE MUNICIPALI- TY}

The local level is very important for the implementation of green economy activities, therefore the authors choose to evaluate the situation in Rezekne municipality as the largest municipality in Latvia in terms of territory and in the largest municipality in Latgale by population [21]. The local level includes municipalities, organizations, entrepreneurs, associations and schools. Focus group task - to evaluate the development level of each criteria in 3 pillars according to 5 categories (not developed / poorly developed / moderately developed / well developed / well developed). The rating is formed by at least 3 of the 4 focus group participants voting for the recognition of one particular rating as appropriate to the local municipality situation. In addition, the authors commented on the main aspects of the discussion and substantiated the evaluation. The authors in Table 1 summarized the focus group assessment on the assessment of green economy development criteria. Evaluations "not developed" and "poorly developed" were combined, but the evaluation "excellent" was not included, since none of the criteria was evaluated like that in the focus group. 
TABle 1. Green Economy Development Criteria Breakdown by Assessment (created by authors)

\begin{tabular}{|c|c|c|c|c|}
\hline \multirow{2}{*}{\multicolumn{2}{|c|}{ 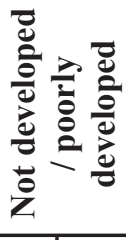 }} & \multicolumn{3}{|c|}{ Assessment of the criterion } \\
\hline & & Moderately developed & Well developed & \\
\hline \multirow{3}{*}{ Uू. } & 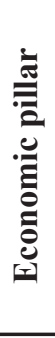 & $\begin{array}{l}\text { - Implementing effective technolo- } \\
\text { gies in business } \\
\text { - Development of eco-tourism } \\
\text { - Eco product development / } \\
\text { export } \\
\text { - Activities of social enterprises } \\
\text { - Implementation of green public } \\
\text { procurement }\end{array}$ & $\begin{array}{l}\text { - Companies operating in the green } \\
\text { sector } \\
\text { - Employment } \\
\text { - Development of infrastructure } \\
\text { - Development of housing infra- } \\
\text { structure } \\
\text { - Tourism and recreation facilities } \\
\text { - Voluntary quality management ini- } \\
\text { tiatives }\end{array}$ & $\begin{array}{l}\text { - Entrepreneurship } \\
\text { - Development level of domestic produc- } \\
\text { tion } \\
\text { - Implementation of investment projects }\end{array}$ \\
\hline & $\frac{\grave{\Xi}}{\bar{E}}$ & $\begin{array}{l}\text { - Involvement of political parties } \\
\text { in environmental issues; } \\
\text { - Resolving demographic chal- } \\
\text { lenges } \\
\text { - Integration of different society } \\
\text { groups }\end{array}$ & $\begin{array}{l}\text { - Environmental education in } \\
\text { schools; } \\
\text { - Development of international } \\
\text { cooperation networks for devel- } \\
\text { opment } \\
\text { - Municipal partnerships; } \\
\text { - Public participation in deci- } \\
\text { sion-making process } \\
\text { - Activities of non-governmental } \\
\text { organizations / associations }\end{array}$ & $\begin{array}{l}\text { - Sustainable development in planning } \\
\text { documents; } \\
\text { - Environmental protection plans and the } \\
\text { achievement of their goals; } \\
\text { - Access to education; } \\
\text { - Availability of public services } \\
\text { - Satisfaction with life }\end{array}$ \\
\hline & 离 & $\begin{array}{c}\text { - RES usage in households } \\
\text { - Waste-free policies } \\
\text { - Certification of energy efficient } \\
\text { buildings } \\
\text { - Heating networks and their } \\
\text { technical condition } \\
\text { - Brownfield revitalisation; } \\
\text { - Use of nature-based solutions; } \\
\text { - Use of environmentally friendly } \\
\text { vehicles. }\end{array}$ & $\begin{array}{c}\text { - Operation of hydroelectric power } \\
\text { stations; } \\
\text { - Use of renewable energy in com- } \\
\text { panies; } \\
\text { - Waste sorting and recycling; } \\
\text { - Energy efficiency } \\
\text { - Limiting water consumption; } \\
\text { - Provision of a centralized and } \\
\text { decentralized sewerage system; } \\
\text { - Development of protected areas; } \\
\text { - Public transport network; } \\
\text { - Availability of bicycle paths. }\end{array}$ & $\begin{array}{l}\text { - Renewable energy resources and their } \\
\text { use; } \\
\text { - The operation of the waste manage- } \\
\text { ment system as a whole; } \\
\text { - Availability of waste collection areas; } \\
\text { - Land-fill management; } \\
\text { - Publicly available green landscapes; } \\
\text { - Water purification systems; } \\
\text { - Flood risk mitigation system; } \\
\text { - Prevention of pollution risks; } \\
\text { - Quality of ground and surface water } \\
\text { resources; } \\
\text { - Management of agricultural land; } \\
\text { - Organic/ biological farming; } \\
\text { - Biodiversity; } \\
\text { - Forest resource management; } \\
\text { - Identification of areas at risk of pollu- } \\
\text { tion; } \\
\text { - Road safety. }\end{array}$ \\
\hline
\end{tabular}

\section{Evaluation of the economic pillar}

In general, it can be concluded that entrepreneurship is developed in Rezekne municipality, but the level of unemployment is still quite high, so there is potential for even bigger business development as there is human resources. More than half of the county's businesses operate in the agricultural sector, so they are subject to a great deal of climate and weather changes. There are not many businesses operating in any kind of green industries, also not many would introduce effective use of technology for environmental protection rather than cost reduction. Attraction of investment in the area is largely due to EU funding that makes development dependent on European policy priorities. As it was concluded, there is great potential for eco-tourism development in the region, as there is a rather large range of water resources that can provide tourism /recreation services, as well as the production of eco-products, but this is still at a development stage, partly due to lack of cooperation between companies/domestic producers. Social entrepreneurship, although not developed in the region, is a potential future trend. This kind of business cannot replace traditional one but can make a big contribution to society as a whole. The Social Business Act, adopted at the end of 2017, states that "A social enterprise is a limited liability company that has been granted the status of a social enterprise in accordance with the procedures laid down in this law and has a positive economic impact (e.g. providing social services, inclusive civil societies, development, education, support for science, protection and preservation of the environment, protection of animals or safeguarding cultural diversity)". Therefore it can be concluded that it is also a sustainable business model, as it directly develops the economy, employment, inclusion of different social groups and the environmental aspects. 


\section{Evaluation of the social pillar}

The social pillar encompasses many diverse aspects where sustainable governance and public involvement can be mentioned as the key. The authors of the paper analysed development documents of the municipality, which can be evaluated positively, although the concept of green economy does not appear in them. However, the aim of the development program and strategy is one - sustainable development, which in turn is a concept closely linked to the green economy. The implementation of the green economy activities ensures this kind of development. As assessed by the focus group, the inclusion of the public in decision-making can have some improvements, as this criterion has been assessed as moderately developed.

When conducting the analysis of municipality development planning documents, the authors concluded that the most important documents in Rezekne Municipality are the Sustainable Development Strategy of Rezekne Municipality 2033 and the Rezekne Municipality Development Program 2019-2023. The following strategic objectives in the documents are: an orderly environment, a creative and educated person and a well-developed business. In general, it can be concluded that the greatest emphasis in the municipality development strategy is on the development of human capital and the promotion of entrepreneurship, while the environmental aspects are emphasized in general as the preservation of natural resources and ensuring an attractive living environment. Environmental aspects are analysed and addressed in the Environmental Report. Compared to the experience of other countries, in particular with the Turku municipality of Finland, it can be concluded that political will plays a major role in development, but it is not emphasize or used in political sphere. At this point, there is no specific development goals in the municipality and sustainable development in the green economy is not emphasized.

After studying the theoretical information base and practical examples from other countries, it can be concluded that public involvement in decision making is very important, if not decisive for the development of a successful policy. Within the focus group, it was concluded that public involvement in decision-making, such as public consultation, is relatively cumbersome. The greatest involvement occurs when there are some significant changes in a particular area, such as environmental pollution, reforms. In order to promote the involvement of the population and draw attention to integration problems, the project CRISCO takes place in the Rezekne municipality. During the project activities representatives of the municipalities' rural units did reports on problems of integration and published them in order to draw the attention of the wider public. Within the framework of the project, the Citizens Advice Council addressed a problem concerning new company that wanted to start unclear recycling enterprise in the village of Strūžāni. As local people were worried about the quality of the environment and there was no clear plan provided by the entrepreneur, this issue drew attention from local governments and the State Environment Service's. Violations were detected and the company's operation was stopped until their issue elimination.
According to the authors, this case demonstrates that the interest of the population is of great importance for providing good living environment.

\section{Evaluation of the environmental pillar}

The environmental pillar includes the use of renewable energy, waste management, green infrastructure, water and land management, sustainable transport and many other aspects. The management of water resources and land resources is generally good. The main problem is the lack of land, as large farmers have already bought most of the area and small farmers who usually are producers of biological production are not able to compete with the price. It is therefore necessary to motivate large farms to consider the idea of producing and exporting organic products, or producing products that have much more added value.

Regarding the use of renewable energy, companies usually lack funding for such large investments, but there are some cases where it is even beneficial. In general, it can be concluded that regulatory enactments related to renewable energy are poor. There are no national legislation, including mandatory procurement components, to encourage entrepreneurs to use renewable energy. Energy efficiency is only topical where EU funds are invested and it is mostly public infrastructure.

Waste management is gradually evolving as a result of EU requirements. The waste-free/ zero-waste policy is currently underdeveloped, but there is possibility to take the great example from the Roubaix municipality in France. The development of a sustainable transport system and the use of environmentally friendly means of transport, following the conclusions of the focus group, may be cumbersome due to the size of the territory in terms of distance that people need to drive and the lack of electric car charging stations.

The potential of Rezekne Municipality to implement green economy activities

It can be concluded that some aspect of green economy is poorly developed in Rezekne Municipality, nevertheless these criteria have the greatest development potential. There is need for attention to the balancing and developing areas of economic activities (mining, construction, alternative energy facilities, etc.) with nature protection interests such as management of existing densely populated and built-up areas, development and efficiency of sewerage and water supply systems, brownfield revitalisation, educating the public about environmentally friendly actions and resource management, as well as building new roads, efficient manufacturing facilities, expanding the range of services in tourism and recreation.

$$
\mathrm{V} \text {. }
$$

\section{CONCLUSIONS}

Sustainable development in the 21 st century is a necessity for countries around the world, taking into account health and the environment arising from the unsustainable management of natural resources. Concepts of green economy and green growth have been very topical in the last decades in seeking solutions that could satisfy consumers' wishes and preserve natural capital in 
order to make responsible use of ecosystem services on which people's well-being depends to the same extent as on economic development. The green economy is based on the three pillars of sustainable development - social, economic and environmental - where only the three together can balance successful growth. The main difference between the traditional and the green economy is that the traditional is based on the use of natural fossil resources, which is both non-renewable and causes pollution and climate change. Developed countries and international organizations are interested in promotion of the concept of the green economy through economic development and implementation of activities based on efficiency, innovation and renewable natural resources.

In order to more actively implement green economy activities, support from policy makers is needed, and the involvement of local authorities. Local activities combine the interests of all stakeholders in a single vision that can be embedded in development planning documents or as an independent strategy for the green economy. Sustainable development assessment can clearly identify weaknesses with the greatest potential for development, but political will, financial support, public education and society participation in processes are needed to change the situation.

The greatest development potential for Rezekne municipality is in promotion of entrepreneurship, gas production from waste, society involvement in nongovernmental organizations to boost green thinking, as well as using direct examples from other countries' municipalities (France, Lithuania, Finland, etc.) who already have experience and real results. Employees of Rezekne municipality should take into account the criteria as "poorly developed" or "medium-developed" (e.g. energy efficiency, ecotourism, social entrepreneurship, brownfield revitalisation, integration of society groups) and include measures for their improvement into the next development plan, to ensure the well-being of citizens and the quality of ecological services.

Latvian municipalities should use the positive aspects of other countries to implement green activities such as hiring an additional employee to promote green economy activities; offering support to associations that educate and motivate citizens to be accountable to the environment; providing financial support in addition to environmental education activities in schools; implementing waste-free initiatives; investing in increasing the use of renewable energy resources; developing strategic plans, taking into account global trends, in order to ensure positive changes in the lifestyle and perception of the population and to improve the competitiveness and development of local governments and thus of the state.

\section{REFERENCES}

[1] K. Pushpam, "Innovative tools and new metrics for inclusive green economy", Current opinion in Environmental Sustainability, Vol. 24., Febr. 2017. [Online]. Available: https://www.sciencedirect. com/science/article/pii/S1877343517300222_[Accessed: April 10, 2018].

[2] E. Dias, "From Brown to Green Economy: Way to Sustainable Development", Panos South Asia Climate Change Blog, Dec. 22, 2012. [Online]. Available: https://climatechange.panossouthasia. org/?p=681 [Accessed: May 11, 2018].

[3] D. Vazquez-Brust, A. M. Smith, J. Sarkis, "Managing the transition to critical green growth: The Green Growth State", Futures, Vol. 64., Dec. 2014. [Online]. Available: https://www.sciencedirect. com/science/article/pii/S0016328714001669 [Accessed: May 11, 2018].

[4] J. A. Puppim de Oliveira, C. N. H. Doll, "Green economy and governance in cities: assessing good governance in key urban economic processes", Journal of Cleaner Production, Vol. 58., Nov. 1, 2013. [Online]. Available: https://www.sciencedirect.com/ science/article/pii/S0959652613005040 [Accessed: May 11, 2018].

[5] United Nations Environment Programme, "Green economy. What do we mean by green economy?", 2012. [Online]. Available: https://ieep.eu/uploads/articles/attachments/3a117c79-3e92-43f1baed-61e3e06f8b2d/KNOSSOS Green Economy Main briefing. pdf? $\mathrm{v}=63664509783$ [Accessed: April 20, 2018].

[6] United Nations Environment Programme, "About green economy". [Online]. Available: https://www.unenvironment.org/exploretopics/green-economy/about-green-economy[Accessed: April 20, 2018].

[7] M. Kḷaviņ̌s, J. Zaḷoksnis, Klimats un ilgtspējīga attīstība. LU Akadēmiskais apgāds, Rīga, 2016

[8] Organisation for Economic Co-operation and Development, "Small states", Economic Review and Basic Statistics, Volume 11, Apr.1, 2007. [Online]. Available: https://www.oecd-ilibrary. org/commonwealth/economics/small-states/culture-as-the-fourthpillar-of-sustainable-development smalst-2007-3-en [Accessed: April 20, 2018].

[9] Europe Environment Agency, "Green economy", June 3, 2016. [Online]. Available: https://www.eea.europa.eu/publications/ europes-environment-aoa/chapter3.xhtml_[Accessed: March 1, 2018].

[10] United Nations, "Green economy", 2017. [Online]. Available: https://sustainabledevelopment.un.org/index.php?menu=1446 [Accessed: March 1, 2018].

[11] Eiropas Savienība, ES investē planētas nākotnē: desmit iniciatīvas modernai un tīrai ekonomikai. Eiropas Savienības Publikāciju birojs, 2018.

[12] A. Sherrard, "Groundbreaking held for Lithuania's largest renewable energy project", Feb. 15, 2018. [Online]. Available: https://bioenergyinternational.com/heat-power/groundbreakingheld-lithuanias-largest-renewable-energy-project [Accessed: April 21, 2018]

[13] LETA, "Sākusi darboties Vil̦nas atkritumu šķirošanas rūpnīca", Dienas Bizness, May 6, 2016. [Online]. Available: http://www. db.1v/zinas/sakusi-darboties-vilnas-atkritumu-skirosanasrupnica-449117 [Accessed: April 21, 2018].

[14] Roubaix City Council, "The story of Roubaix", Case study Nr.8. [Online]. Available: http://zerowasteeurope.eu/wp-content/ uploads/edd-free-downloads-cache/CS8-Roubaix.pdf [Accessed: April 28, 2018]

[15] SSE Electricity, "What is Green Deal?". [Online]. Available: https:// sse.co.uk/help/energy/energy-efficiency/green-deal_[Accessed: April 28, 2018].

[16] Green Deal: energy saving for your home. [Online]. Available: https://www.gov.uk/green-deal-energy-saving-measures [Accessed: April 28, 2018].

[17] J. Rosenow, N. Eyre, "A post mortem of the Green Deal: Austerity, energy efficiency, and failure in British energy policy", Energy Research \& Social Science, Vol. 21, 2016. [Online]. Available: https://www.sciencedirect.com/science/article/pii/ S2214629616301803 [Accessed: April 28, 2018].

[18] J. Rosenow, N. Eyre, "A post mortem of the Green Deal: Austerity, energy efficiency, and failure in British energy policy", Energy Research \& Social Science, Vol. 21, 2016. [Online]. Available: https://www.sciencedirect.com/science/article/pii/ S2214629616301803 [Accessed: April 28, 2018].

[19] M. Fuller, C. Kunkel, M. Zimring, "Driving Demand for Home Energy Improvements", Lawrence Berkeley National Laboratory, Berkeley, Sept. 2010. [Online]. Available: https://emp.lbl.gov/ publications/driving-demand-home-energy [Accessed: April 28, 2018].

[20] H. Pettifor, C. Wilson, "The appeal of the green deal: Empirical evidence for the influence of energy efficiency policy on renovating homeowners", Energy Policy, Vol. 79, April 2015. [Online]. Available: $\quad$ https://www.sciencedirect.com/science/article/pii/ S0301421515000166 [Accessed: April 28, 2018].

[21] Pilsonības un migrācijas lietu pārvalde, "Latvijas iedzīvotāju skaits pašvaldībās”, 2018. [Online]. Available: http://www.pmlp. gov.lv/lv/assets/documents/1aaaa/ISPV Pasvaldibas iedzivotaju skaits.pdf [Accessed: May 12, 2018]. 